УДК 373.5.091.398

Мар'яна Гладкевич, викладач кафедри теоретичної та консультативної психології Національного педагогічного університету імені М.П. Драгоманова, м. Київ Ольга Заяць, кандидат педагогічних наук, доцент, директор Дрогобицького педагогічного ліцею Юрій Кишакевич, кандидат фізико-математичних наук, професор

\title{
ПІДГОТОВКА ДО ЗНО: ШКОЛА ЧИ РЕПЕТИТОРСТВО?
}

Для сьогоднішніх дітей проблема репетиторства є актуальною. I особливо розповсюджене репетиторство саме під час підготовки до ЗНО.

На прикладі Дрогобищького педагогічного лічею автори вивчили стан розповсюдження репетиторства серед випускників і стверджують, що воно може допомагати краще підготуватися до ЗНО тільки деяким категоріям випускників і не повинно охоплювати усіх.

Вчителі повинні застосовувати широкий спектр заходів для посилення індивідуальної роботи з учнями, які мають труднощі у засвоєнні знань з певних предметів; мають увести у систему роботи 3 випускниками протягом року знайомство з тестами ЗНО минулих років і на иій підставі переконувати їх, що організація повторення пройденого раніше матеріалу з підручника і старанне виконання завдань під час звичайних занять є гарантом успішної підготовки до ЗНО. Посилити роз'яснювальну роботу серед батьків і випускників про шкідливі впливи репетиторства на стан здоров'я дітей.

Ключові слова: репетиторство, ЗНО, учитель, репетитор, тести, перевантаження, стан здоров'я, вимушене репетиторство, плата за репетиторство.

Jim. 7.

Maryana Hladkevych, Lecturer of the Theoretical and Advisory Psychology Department National Mukhaylo Drahomanov Pedagogical University, Kyiv Olha Zayats, Ph.D.(Pedagogy), Associate Professor, Director of Drogobych Pedagogical Lyceum Yuriy Kyshakevych, Ph.D.(Physics and Mathematics), Professor

\section{PREPARING FOR EXTERNAL TESTING: SCHOOL OR TUTORING?}

Nowadays, the problem of tutoring is relevant for children. Moreover, the tutoring is especially widespread precisely when preparing for external testing.

By the example of the Drogobych Pedagogical Lyceum, the authors have studied the state of distribution of tutoring among graduates and argue that it can help better prepare for EIT only for certain categories of graduates and should not cover everyone.

Teachers should apply a wide range of activities to enhance the individual work with students who have difficulties in mastering knowledge of certain subjects; should introduce into the system of work with graduates during the year acquaintance with the tests of external testing of past years and on this basis to persuade them that organizing the repetition of previously passed material of the textbook and diligent performance of tasks during regular classes is a guarantor of successful preparation for external testing. Strengthen the educational work among parents and graduates concerning the harmful effects of tutoring on children's health.

Keywords: tutoring, external training, a teacher, a tutor, tests, overload, health condition, forced tutoring, tuition fees.

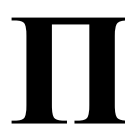

остановка проблеми. Розподіл ролі школи і репетиторства при підготовці випускників до ЗНО є предметом занепокоєння педагогічної громадськості. Останнім часом склалася така громадська думка, що без репетиторства випускники загальноосвітньої школи не можуть успішно скласти ЗНО. Тим самим применшується роль школи у підготовці до заключного етапу навчання - проведення ЗНО або державної підсумкової атестації. Крім того, батьки несуть додаткові витрати на оплату праці репетиторів. За підрахунками авторів деяких сайтів батьки змушені витрачати на оплату репетиторів за рік до 32 тисяч гривень. Заняття з репетиторами викликає перевантаження випускників в останньому навчальному році, що негативно впливає на їх стан здоров'я. Стаття $\epsilon$ продовженням досліджень,висвітлених у статтях $[1 ; 2]$.

Метою статті є вивчення реальної потреби у репетиторстві випускників загальноосвітньої школи, а також мінімізація негативних впливів репетиторства як на сімейний бюджет батьків випускників, так і на стан здоров'я випускників.

Аналіз останніх публікацій. Директор Американських рад з міжнародної освіти ACTR/ ACCELS, заступник директора програми сприяння зовнішньому тестуванню в Україні (USET) пише: “... отримані бали (на ЗНО - авт.) 
свідчать не лише про якість викладання в навчальних закладах, а й про роботу репетиторів, самопідготовку майбутніх абітурієнтів тощо" [3].

Директор українського центру оцінювання якості освіти І.Лікарчук заявляє: “Більше того, результат, отриманий під час зовнішнього оцінювання, далеко не завжди залежить від роботи конкретного вчителя чи школи. Репетитори, підготовці курси, самостійна робота, батьківська оцінка, індивідуальні особливості кожної дитини так чи інакше впливають на те, як вона засвоює знання. Ідеальним варіантом $\epsilon$ той, коли все це доповнюється гарною роботою вчителя i конкретної школи. Однак таке поєднання, на жаль, буває далеко не завжди” [4].

Виклад основного матеріалу. Щоб вивчити стан використання репетиторства серед випускників Дрогобицького педагогічного ліцею, було проведено їх анкетування. Випускники Дрогобицького ліцею 2018 року відповіли на запитання анкети, зміст якої такий:

Анкета для випускників ліцею

1.Ставлення до репетиторів:

Відповіді:

1.1. Я маю репетиторів з таких предметів: (перерахувати):

1.2. Я не маю репетиторів.

Обведіть номер вашого варіанту відповіді.

2. Мій репетитор Відповіді:

2.1 вчитель лічею

2.2. вчитель іншої иколи

2.3. викладач університету або коледжу.

Обведіть номери ваших варіантів відповіді (можливо, не один).

3. При підготовці до ЗНО я віддаю перевагу репетитору, бо

\section{Відповіді:}

3.1. репетитор дає відповіді на конкретні питання тестів;

3.2. репетитор вчить вгадувати відповіді на тестові питання у сумнівних випадках;

3.3. на думку батьків та знайомих підготуватися до ЗНО без репетиторства неможливо;

3.4. між тестами $3 Н О$ і матеріалом, що викладається у ліцеї, є невідповідність;

3.5. лічей майже незастосовує багатоваріантні тестові завдання;

3.6. інша причина, а саме:

Обведіть номери ваших варіантів відповіді (можливо, не один).

4. Учителі ліцею переконували вас, що можна скласти $3 \mathrm{HO} з$ допомогою звичайних занять у ліцеї.
Відповіді: так, ні, іноді

Обведіть Ваш варіант відповіді.

5.Учителі ліцею знайомили вас 3 минулорічними версіями тестів $3 \mathrm{HO}$

Відповіді: так, ні, іноді

Обведіть Ваш варіант відповіді.

В анкетуванні взяло участь 91 учень ліцею, 3 них тільки 10 або 11\% не мають репетиторів, а $89 \%$ мають репетиторів 31 предмету 24 або 26 \%, 32 предметів 24 або 26 \%, 33 предметів 29 або 32 \%, 34 предметів 4 або 5\%.

Відзначимо, що в ліцеї проводиться велика роз'яснювальна робота серед випускників та їх батьків щодо підготовки до ЗНО. Батьків переконують, що учні ліцею цілком успішно можуть підготуватися до ЗНО підчас занять в ліцеї, зокрема у розклад занять додатково уведено “підготовку до 3НО”. На заняттях ліцеїстів знайомлять 3 минулорічними версіями тестів. Учні повторюють матеріал, що вивчався у 5 - 7 класах. Підставою для таких тверджень $є$ велика кількість призових місць, зайнятих щороку ліцеїстами на усіх етапах Всеукраїнської учнівської олімпіади. Учителі ліцею ознайомлені з ухвалою педагогічної ради закладу, що надання ними послуг репетитора учням ліцею розцінюється як корупційне діяння. Батькам розповідають про перевантаженість випускників, які готуються до ЗНО з допомогою репетиторів.

Анкетування показало, що ліцеїсти і їх батьки піддалися поширеній сумнівній думці, що без репетиторів підготуватися до ЗНО неможливо. Якщо свої вчителі не можуть бути репетиторами, то слід вдатися до вчителів інших шкіл або викладачів університету. 57 випускників ліцею віддали перевагу як репетиторам - учителям 3 інших шкіл, 33 ліцеїсти обрали за репетиторів викладачів університету (не тільки Дрогобицького державного педагогічного університету, а й інших), 4 ліцеїсти не вказали заклади, в яких працюють їхні репетитори, 3 випускники ліцею мають все-таки репетиторів 3 числа вчителів ліцею. Слід зазначити, що низка випускників має двох або більше репетиторів.

Дещо суперечливими є відповіді ліцеїстів на 4 i 5 питання анкети. Тільки 5 ліцеїстів не чули, як вчителі ліцею переконували випускників, що не потрібно вдаватися до послуг репетиторів для підготовки до ЗНО. Ще 64\% ствердно відповіли, що вчителі ліцею переконували їх у достатності звичайних занять у ліцеї для успішної підготовки до ЗНО і знайомили їх з минулорічними версіями тестів ЗНО. Решта ліцеїстів - 29\% - вважають, що вчителі ліцею несистематично знайомили їх 3 


\section{ПІДГОТОВКА ДО ЗНО: ШКОЛА ЧИ РЕПЕТИТОРСТВО?}

версіями тестів минулих років і переконували їх не вдаватися до послуг репетиторів.

Суперечність бачимо у тому, що вчительпредметник проводив або розповідав про роль репетиторів у підготовці до ЗНО цілому класу, тобто охоплював цією формою роботи усіх присутніх, а не тільки дві третини, як це випливає 3 анкет випускників.

Ось що висловила міністр освіти та науки України Лілія Гриневич [5].

“Ми проти вимушеного репетиторства. Взагалі ця розмова інтенсифікувалася, коли Організація економічної співпраці і розвитку представила звіт про фактори недоброчесності в освіті України. Наприклад, таким фактором може бути черга в дошкільні заклади, бо це продовжує корупційні зв'язки. I один із шести представлених факторів - вимушене репетиторство. Вимушене репетиторство, це коли дитина недоотримує від вчителя достатньої підготовки під час навчального процесу в школі, а потім вчитель говорить, що “з вашою дитиною необхідно додатково позайматися за гроші”. Зрозуміло, це не повсюдна ситуація, але вона має місце, i експерти, які робили цей звіт, застерегли проти неї. Ми розуміємо, що це справді не доброчесна ситуація, але скасувати репетиторство як явище абсолютно ніхто не збирається, і це неможливо, тому що репетиторство - це можливість індивідуально працювати на потреби дитини.

Але для сьогоднішніх дітей проблема репетиторства $\epsilon$ актуальною. I особливо розповсюджене репетиторство саме під час підготовки до ЗНО".

Таким чином, міністр освіти і науки України визнає, що репетиторство під час підготовки до ЗНО є розповсюдженим явищем.

Вчителі ліцею мають увести у систему роботи 3 випускниками протягом року знайомство 3 тестами ЗНО минулих років і на цій підставі переконувати їх, що організація повторення пройденого раніше матеріалу з підручника i старанне виконання завдань під час звичайних занять у ліцеї є гарантом успішної підготовки до 3НО.

Мотивація випускників вдатися до послуг репетиторів різноманітна. Часто ліцеїсти вказують на кілька факторів одночасно.

29 анкетованих вважають, що репетитор "натаскує" їх, тобто або дає готові відповіді на питання тестів, або вчить вгадувати відповідь у сумнівних випадках.

17 випускників вдалися до репетиторів під впливом батьків або знайомих, які переконували їх, що без репетиторів неможливо підготуватися до ЗНО.
Ще 6 ліцеїстів вдалися до послуг репетиторів, бо у ліцеї майже не застосовують багато інваріантні тестові завдання.

Помітили невідповідність між тестами ЗНО і матеріалом, що викладається у ліцеї, 10 ліцеїстів. Це теж спонукало їх готуватися до $3 \mathrm{HO} 3$ допомогою репетиторів.

Відзначимо, що апріорі таких розбіжностей не повинно бути. На нашу думку, ця невідповідність завдань 3 предмету і тестових питань на $3 \mathrm{HO}$ більше лежить у психологічному плані. Випускники загальноосвітніх навчальних закладів мало стикаються у шкільній практиці 3 багатоваріантними тестовими завданнями. I це зрозуміло: підготовка таких завдань займає у вчителя багато часу. Розмноження тестових завдань передбачає наявність розмножувальної техніки, достатньої кількості паперу. Відзначимо, що тільки кожен дев'ятий випускник заявив, що на заняттях у ліцеї не застосовували багатоваріантних тестових завдань.

24 ліцеїсти визначили інші підстави, які штовхнули їх до репетиторів. Найважливіші з них:

- брак знань матеріалу, який вивчали у 7 - 9 класах;

- посилення впевненості у своїх знаннях;

- переваги індивідуального навчання над груповим;

- потреба у додаткових заняттях з предмету, який важко засвоюється у ліцеї.

Ці факти наводять на думку, що учительський колектив ліцею ще недостатньо переконує як учнів так і батьків у відсутності потреби участі репетиторів у підготовці до ЗНО.

Витрати на репетиторів краще спрямувати на оздоровлення випускників, на дотримання ними здорового способу життя: участь у художній самодіяльності, спорті, туризмі. Про розміри цих витрат ось що пише “Львівська пошта" [6] :

"Підготовка до ЗНО: готуйте... 30 тисяч

“Львівська Пошта”, поспілкувавшись із львівськими репетиторами та промоніторивши різні сайти, підрахувала, скільки в середньому коштуватиме підготувати учня до ЗНО-2018. Найпопулярніші категорії репетиторів в Україні: українська мова та література, математика, історія України та англійська мова. Переважно репетитори вказують ціну за годину заняття. Так, у середньому година заняття 3 української мови коштує $80-120$ грн; математики - $100-150$ грн; історії - 70 - 100 грн. Що стосується англійської мови, то ціни варіюються від 100 до 300 грн за годину. До слова, часто репетитори з англійської мови вказують ціну в іноземній валюті. Загалом вартість додаткових занять залежить від того, чи 


\section{ПІДГОТОВКА ДО ЗНО: ШКОЛА ЧИ РЕПЕТИТОРСТВО?}

репетитор - вчитель у школі, чи викладач вишу, який у нього досвід та наскільки успішно проходили ЗНО учні, яких він готував.

Отож, виходячи 3 цін, підрахуємо приблизну загальну вартість:

Українська мова та література: 2 год * 2 уроки на тиждень $* 4$ тижні * 8 місяців $* 80$ грн/год $=10$ 240 грн.

Математика: 2 год * 2 уроки на тиждень * 4 тижні * 8 місяців * 100 грн/год $=12800$ грн.

Історія України: 2 год * 2 уроки на тиждень * 4 тижні * 8 місяців * 70 грн/год $=8960$ грн.

Таким чином, підготовка до 3НО-2018 3 репетиторами із трьох предметів за вісім місяців обійдеться щонайменше 32000 грн”.

Спробуємо обчислити тижневий робочий час випускника загальноосвітнього навчального закладу, який додатково працює з репетиторами 3 двох, трьох або чотирьох предметів.

Тижневий бюджет часу складає 168 год., 3 них одну третину припадає на сон. Отже, разом 3 неділею у випускника залишається 112 годин. Заняття у школі і виконання заданої самостійної роботи складає 36год +36 год $=72$ год. Заняття 3 репетиторами з 3-х предметів і виконання завдань репетиторів забирає 12 год +12 год = 24 год. Таким чином, робочий час випускника у тижні (разом 3 неділею) складає 72 год +24 год $=96$ год. На відпочинок залишається: 112 год -96 год $=16$ год. Якщо доросла людина працює 40 год на тиждень, то випускник середнього загальноосвітнього закладу - 96 год. Ці цифри слід довести до відома вчителів, батьків та широкої громадськості, щоб переконати усіх, що репетиторство є вагомим фактором погіршення здоров'я шкільної молоді. Зі статистики відомо, що 95\% випускників середньої школи мають ті чи інші захворювання. 3 такою організацією навчального процесу школа плюс репетиторство - не можна миритися, воно шкодить здоров'ю нації.

Практика останніх років показує, що учні XI класів у другій половині навчального року (а дехто і у першій) ігнорують уроки з предметів, з яких вони не проходитимуть ЗНО. У вивільнений час учні працюють $з$ репетиторами. Їх мотивація проста: в атестаті з цих предметів якась оцінка буде, а середній бал атестату при вступі до вищої школи і так множиться на певний коефіцієнт 0,1 - 0,2, що мало вплине на конкурсний бал.

Витрати часу та коштів учениці сільської школи на послуги репетиторів 3 обласного центру Львова: “Торік 18-річна Марія Біжик вісім місяців двічі на тиждень їздила до репетиторів в обласний центр із рідного села Боберка Турківського району. На дорогу туди й назад витрачала 5 год.,
90 грн щоразу йшло на квитки. Набрала на $3 \mathrm{HO}$ 168 балів з історії України, 160 із німецької мови, 159 з української мови та літератури. Вступила на платну форму навчання факультету іноземних мов університету ім. Франка. За рік віддає 10 тис. 300 грн.

- Якби зараз час повернути, по-іншому поставилася би до навчання, - розказує. Зустрічаємося на перерві між парами. - Напевно, змогла би вступити і без репетиторів на платне. Не пропускала б уроки з німецької, української та історії. 2 години щодня треба самостійно повторювати ці предмети” [7].

Висновки. Результати тестування ліцеїстів свідчать про таке:

- репетиторство серед випускників загальноосвітнього закладу не повинне бути загальноохоплюючим;

- до послуг репетиторства можуть вдаватися ті випускники, які слабо засвоїли матеріал 7 - 9 класів або їм важко дається якийсь предмет (наприклад, англійська мова);

- система повторення матеріалу, який вивчали випускники у 7 - 10 класах, повинна бути розрахована на весь навчальний рік;

- вчителі предметів повинні застосовувати багатоваріантні тестові завдання у навчальному процесі 10 - 11 класів та знайомити учнів 3 минулорічними версіями тестів 3НО;

- вчителі повинні застосовувати широкий спектр заходів для посилення індивідуальної роботи $з$ учнями, які мають труднощі у засвоєнні знань $з$ певних предметів;

- керівництво ліцею має посилити роз'яснювальну роботу серед батьків і випускників про шкідливі впливи репетиторства на стан здоров'я дітей.

\section{ЛITЕРАТУРА}

1. Кишакевич Ю.Л., Заяць О.В. Підготовка студентів педагогічних університетів до проведення зовнішнього незалежного тестування знань випускників шкіл //Молодь і ринок. - 2009. №1. - C.13-15.

2. Кишакевич Ю.Л., Заящь О.В. Ставлення учителів до ЗНО // Молодь і ринок. - 2009. - №11. C.14-17.

3. Пенжола-Вітович. Вступна стаття. Вісник TIMO. - 2008. - C.7-8.

4. Лікарчук I. Зовнішнє оцінювання-найбільша реформа в освіті України.// Управління освітою. - 2008. - № 34.

5. Гриневич Лілія. Інтерв'ю на каналі ТСН 25 квітня 2017. Режим доступу: https://tsn.uа/ interview/skasovuvati-repetitorstvo-absolyutno-nihtone zbirayetsya-919588. html

6. ЗНО - 2018: Репетитори чи самоосвіта?// Львівська пошта - 2018. - №10 (2022). - 3 лютого. 
7. Ольга Швед, Ірина Зджанська. “Половина мого класу ходили до репетиторів"//Газета поукраӥнськи. - 2012. - 19 листопада.

\section{REFERENCES}

1. Kyshakevych, Yu.L. \& Zaiats, O.V. (2009). Pidhotovka studentiv pedahohichnykh universytetiv do provedennia zovnishnoho nezalezhnoho testuvannia znan vypusknykiv shkil [Preparation of students of pedagogical universities for external independent testing of knowledge of graduates of schools]. Youth and market, no.1, pp.13-15.[in Ukrainian].

2. Kyshakevych, Yu.L. \& Zaiats, O.V. (2009). Stavlennia uchyteliv do ZNO[The attitude of teachers towards external testing]. Youth and market, no.11, pp.14-17.[in Ukrainian].

3. Penzhola-Vitovych (2008). Vstupna stattia
[Introductory article]. Visnyk TIMO, pp.7-8.[in Ukrainian].

4. Likarchuk, I.(2008). Zovnishnie otsiniuvannia naibilsha reforma $v$ osviti Ukrainy[External evaluation is the biggest reform of Ukrainian education]. Education Management, no. 34.[in Ukrainian].

5. Hrynevych Liliia. Interviu na kanali TSN 25 kvitnia 2017 [Interview on the TSN Channel April 25,2017]. Retrieved from: https://tsn.ua/interview/skasovuvati-repetitorstvoabsolyutno-nihto-ne zbirayetsya-919588.html[in Ukrainian].

6. ZNO - 2018: Repetytory chy samoosvita? [External testing - 2018: Tutors or self-education?]. Lviv post office, no.10 (2022), february 3.[in Ukrainian].

7. Olha Shved \& Iryna Zdzhanska (2012). "Polovyna moho klasu khodyly do repetytoriv"["The half of my class went to the tutors"]. Newspaper in Ukrainian, November 19. [in Ukrainian].

Стаття надійшла до редакції 05.02.2018

УДК 378.1

Володимир Ткаченко, кандидат фізико-математичних наук, дочент, докторант Центральноукраӥнського державного педагогічного університету імені Володимира Винниченка Дмитро Хаперець, студент фізико-математичного факультету очної форми навчання на 2-му (магістерському) рівні ДВНЗ “Донбаський державний педагогічний університет”

\section{ВІДПОВІДНІСТЬ СТУПЕНЯ СФОРМОВАНОСТІ КОМПЕТЕНЦЙ ВЧИТЕЛЯ РІВНЮ ЙОГО КОМПЕТЕНТНОСТІ В ОБЛАСТІ ІНФОРМАЦЙНО- КОМУНІКАЦЙНИХ ТЕХНОЛОГІЙ}

У статті висвітлюються теоретичні засади проблеми впливу ступеня сформованості компетениій на рівень компетентності в області інформаційно-комунікаційних технологій вчителя. Проаналізовано поняття “компетенція”, “компетентність”, “ІКТ-компетентність”. Представлено структуру рівнів IКТкомпетентності вчителя. Розглянуто зміст трьох рівнів IКТ-компетентності: технологічної грамотності, поглиблення та створення знань.

Ключові слова: компетениія, компетентність, компетентнісний досвід, компетентнісноорієнтований підхід, ІКТ-компетентність.

Табл. 2. Літ. 5.

Volodymyr Tkachenko, Ph.D.(Physics and Mathematics), Associate Professor, Doctoral student of Central Ukrainian Volodymyr Vynnychenko State Pedagogical University Dmytro Khaperets, Student of the Faculty of Physics and Mathematics at the 2nd (Master) level of State Higher Education Institute "Donbass State Pedagogical University"

\section{CONFORMITY OF THE DEGREE OF THE FORMATION OFTHE TEACHER'S COMPETENCES WITH THE LEVEL OF THE COMPETENCE IN THE FIELD OF INFORMATION-COMMUNICATION TECHNOLOGIES}

The article is devoted to the analysis of literary data concerning the list and content of those competencies groups on the basis of which the teacher's ICT competence is formed. In the question of the structure of the professional competence of the teacher there is no single approach. These differences are related to the distribution, detailing and strengthening of individual competencies. This leads to the fact that in publications there is a wide variety of competence groups in the structure of the teacher's professional competence. At the same time, practically all scientists distinguish the competence of ICT as an obligatory component of the teacher's professional competence. UNESCO International Recommendations ICT-CFT on the structure of ICT competence of teachers confirm this.

Teachers of the world community proceed from the combination of the state's economic development and 